\title{
THE BIRDS OF IMONSERRAT
}

\author{
By Stuart T. Danforh

\section{College of Agriculture and Mechanic Arts, University of Puerto Rico, Mayagüez, Puerto Rico.}

Monserrat is one of the islands of the British Leeward Islands colony. It is 25 miles southwest of Antigua, 35 miles southeast of Nevis, and about the same distance northwest of Guadeloupe. It lies in latitude $16^{\circ} 45^{\prime} \mathrm{N}$., and longitude $61^{\circ} \mathrm{W}$., and is about 11 miles long by 7 miles wide, with an area of 32 square miles. It is in the form of an oval tapering towards the north, and is a rugged, mountainous island of volcanic formation.

There are two principal groups of mountains, the Soufriere system in the southern part of the island, and the Centre Hills in the central and north central part. The former group includes Gage's Mountain, Chance's Mountain, the Soufriere Peak, Cassel's Peak, South Soufriere, and other peaks. At least some of these mountains are actively volcanic, possessing a number of craters emitting hydrogen sulphide and other noxious gases, sulphur, steam, and boiling water discolored by compounds of volcanic origin which it holds in solution. Within the past decade these were the scene of more violent activity, producing a series of earthquakes and other phenomena which alarmed the populace and did considerable damage. The highest peak in this system (Soufriere Peak) attains an altitude of 3,002 feet.

The Centre Hills are somewhat lower (the highest point being a peak of only 2,450 feet) and they are not actively volcanic.

The upper parts of both mountain groups are clothed with virgin rain forest, which does not usually extend below an elevation of from 1,500 to 2,000 feet. However, at the estate known as Woodlands (on the north central part of the leeward coast) this mountain fores reaches down from the Centre Hills to the surprisingly low elevation of 800 feet above sea level. Here such typically mountain birds as the oriole and trembling thrush may be observed with slight effort by merely taking a short walk from the highway. If this fascinating and easily accessible forest could be preserved for posterity it could easily become one of the great natural attractions of this beautiful little island, already blessed with an assortment of them far out of proportion to its size. 
Montserrat possesses no extensive mangrove swamps, due to the abruptness of its coastline, which in many places is composed of cliffs, forming nesting places for tropical birds. There are no fresh water ponds or lakes, and the only brackish water pond large enough to merit the name is that near Elberton, usually known as Fox's Bay Pond, on the leeward coast a few miles to the north of Plymouth. It covers an area of perhaps ten acres, and is for the most part very shallow with such a large number of mangroves growing in it that from a distance it appears more like a woodlot than a pond. However, in the center there is a small-area of open water somewhat less than an acre in extent, invisible until one reaches it. Here pied-billed grebes, coots, gallinules, and possibly other water birds nest.

At lower elevations near the sea there are some dry, brush covered hillsides where many varieties of birds may be found, and some densely wooded ravines or guts are always points of attraction for the ornithologist.

Some information which has come to hand concerning the island of Redonda is also included in this paper. Redonda is a small uninhabitated rocky island situated north of Montserrat approximately half way between that island and Nevis. It consists chiefly of a plateau surrounded by rocky precipices descending abruptly to the sea, making the plateau very difficult of access. Large numbers of seabirds nest there practically unmolested due to the isolation and inaccessibility of the island.

The first person to make collections of Montserrat birds of whom we have any record was J. E. Sturge of Plymouth, who in 1879 prepared and sent 17 species of birds to the British Museum. These were reported upon by P. L. Sclater (Proceedings of the Zoölogical Society of London, 1879, pp. 764-765).

Fred A. Ober, collecting for the Smithsonian Institution, visited the island on his second West Indian expedition in the latter part of 1880. Among the specimens he obtained were 7 examples of $I c$ terus oberi, including the type, the description of which was published by G. N. Lawrence (Proceedings of the U.S. National Museum, 3, 1881, p. 351), but no complete report on his Montserrat collections was ever published. However, references to a number of specimens collected by him are made by Ridgway (U.S. National Museum Bulletin 50, 190--1919). Most of these birds are now in the Field Museum of Natural History.

T. Grisdale spent the month of February 1881 in Montserrat, living at an altitude of 1,200 feet at the edge of the virgin forest. 
He confined his work almost entirely to the mountains, and collected 14 species, 7 of which had not been obtained by Sturge. He published a report of his collections and observations in the Ibis (1882, pp. 485-493).

Michael J. Nicoll, cruising in the West Indies on the "Valhalla", R.Y.S., spent the day of February 11, 1904 on Monserrat, and collected 10 species, including three species of migrant warblers not previously know from the island. He published a report on the birds collceted on this cruise in the Ibis (October, 1904, pp. 555-591).

T. Savage English, of England, who had previously resided in Grand Cayman, took up his residence in Montserrat in 1919, and has lived there continuously ever since. He has made numerous observations on the natural history of the island, and has published an account of the nesting of Orthorhynchus cristatus exilis in Montserrat (Ibis, January, 1928, pp. 13-16).

James Bond, of the Academy of Natural Sciences of Phidalphia, made collections on Montserrat during the latter part of December, 1929. No complete report on his work on the island has been published, although he makes many references to Monserrat birds in his "Birds of the West Indies", (1936).

The present author made fours short in transit visits to the island on July 22, 1922 (when he ascended to one of the craters on the Soufriere Mountain), July 31, 1931, June 30, 1935 (when a few nests and eggs were collected), and on August 13, 1935. Ornithological observations were made on all of these brief visits. In 1937, in the course of a rather extended ornithological expedition to the Lesser Antilles, accompanied by Gustavo Biaggi as assistant, he spent the period from February 6 to February 20 on the island. During this period about 70 specimens were collected, representing the majority of the resident species and a few that are migratory. Since then our collections have been supplemented by specimens sent by Reginald A. Tonge of Plymouth, filling in weak spots in our collections, and greatly enhancing the value of the whole.

Prior to our visit there were published records of 44 species known from the island, excluding two which should be regarded as doubtful. In this paper fourteen species are recorded from the island for the first time, bringing the known avifauna of the island to 58 species definitely known to occur there.

In conclusion, it is a pleasure to mention our gratitude to various people in Montserrat who assisten in our work. First we must mention His Honour, T. E. P. Baynes, O. B. E., Commissioner of Montserrat, for his courteous and gracious assistance in granting us 
permission for collecting and placing other government facilities for work at our disposal.

Mr. T. Savage English, the naturalist who has resided in Montserrat for many years, provided us with information which proved invaluable in our work, and the keen and benevolent interest which he took in our endeavours at all times was a pleasure to experience.

Mr. Swithin A. Schouten, Acting Curator of the Montserrat Botanical Gardens, was of much assistance to us both in official and friendly capacities, helping us to plan our work on the island, making arrangements for transportation and guides, and in other ways.

An annotated list of the birds known from the island follows.

\section{Podilymbus podiceps antillarum Bangs}

ANTILLEAN PIED-BILLED GREBE

Diver

R. A. Tonge has sent me an adult male collected on Fox's Bay Pond on February 26, 1938 (the wing of which measures 125.4 millimeters), and another collected May 4, 1938; also he states were taken at the nest at the same locality on September 1, 1937. The only previous record I find is of a specimen in the British Museum collected by Sturge in 1879 .

\section{Puffinus lherminieri lherminieri Lesson AUDUBON'S SHEARWATER}

There is a specimen in the British Museum collected by Sturge in 1879. I observed one at sea near Redonda on June 17, 1931.

\section{Phaëthon aethereus mesonauta Peters}

RED-BILLED TROPIC BIRD

Trofic

Apparently not previously known from the island. In February 1937 the species was observed commonly along the western coast of the island, breeding wherever there were suitable cliffs from Fox's Bay northward. R. A. Tonge has sent me an adult male and a specimen with the sexing lost taken at Garibaldi Hill on March 20, 1937, and a pair of adults collected at Rendezvous on February 7, 1938. 


\section{[Phaëton lepturus catesbyi Brandt}

YELLOW-BILLED TROPIC BIRD

Bond (Birds of the West Indies, p. 8) states that he observed this species at Montserrat, but in view of the fact that he obtained no specimens, and that the common breeding bird of the island is unquestionably the red-billed species, I regard this record as unsatisfactory.]

\section{Pelecanus occidentalis occidentalis Linnaeus}

\section{WEST INDIAN BROWN PELICAN}

Observed along the coast near Plymouth and Fox's Bay in February, 1937. Not previously recorded from the island.

\section{Sula leucogaster leucogaster Boddaert}

\section{BROWN BOOBY}

Not yet recorded from Montserrat. On July 18, 1938 Messrs. H. E. Box, Hay Bryson, and A. Moore, of Antigua, visited Redonda, and found thousands of boobies breeding on the plateau. Some had eggs and others young at that time. They report that the nests were so thick and the birds so tame that it was difficult not to walk on them.

\section{Fregata magnificens rothschildi Mathews}

\section{MAN-O-WAR BIRD}

Frigate

Three observed at Plymouth on July 31, 1931, and one along the northwest coast on February 6, 1937, constitute the first records for the island.

\section{Ardea herodias adoxa Oberholser}

\section{WEST INDIAN GREAT BLUE HERON}

Sturge sent a juvenile specimen to the British Museum many years ago. R. A. Tonge has sent me an adult male collected at Cars Bay, in the north of the island, on December 16, 1937, and an adult female taken at the same place on January 18, 1938.

The status of the race or races of this heron inhabiting the West Indies is a matter of doubt. The rather scanty evidence available seems to indicate the existence of a resident race adoxa, supplemented by migrants of herodias from North America in winter. More data is needed to clear up this point. In the meanwhile these specimens 
are listed provisionally as adoxa. The male measures, wing 489; tail 176.4; eulmen from base 158; tarsus 179.6 , and the female wing 429.2; tail 166.3, eulmen from base 140.3 and tarsus 159 millimeters.

\section{Egretta thula thula (Molina) \\ SNOWY EGRET}

The only record is of a specimen sent by Sturge to the British Museum.

\section{Florida caerulea cuerulescens (Latham)}

\section{LITTLE BLUE HERON}

Apparently very scarce. One in immature plumage was seen at Fox's Bay Pond February 11th and 12th, 1937, and R. A. Tonge sent an adult female taken at Isles Bay, April 7, 1938. Not previously recorded from the island.

\section{Butorides virescens maculatus (Boddaert)}

WEST INDIAN GREEN HERON

\section{Water Witch}

Common and generally distributed, being often found far from water and even high in the mountains, where I have seen it on Cassel's Peak at elevations of over 2,500 feet, and on Olveston Mountain it was common up to 1,500 feet in clearings and banana plantations. At lower elevations it frequents dry fields and pastures as well as the vicinity of water. Females were collected by a sulphurated water stream just below a crater on the Soufriere Mountain on February 9, and at a small damp spot in the uplands near Plymouth on February 8. The stomach of the former was nearly empty, containing merely a few insect remains; that of the latter contained 120 bluebottle flies (Pyrellia ochricornis), a large moth, a grasshopper and 3 Anolis lizards. Since then R. A. Tonge has sent me a pair collected at Fox's Bay Pond on January 20, 1938.

These specimens are all typical of maculatus, both in size and color. In fact, the male exhibits the smallest measurements of all the West Indian examples in my collection. The measurements of these specimens are as follows: 1 adult male, wing 155.3; tail 53.2; exposed culmen 59.8 ; tarsus 47.5 . 3 adult females, wing 162.3-170.7 (165.9); tail 58.2-64.1 (60.6); exposed culmen 53.4-58.2 (55.6); tarsus $46-46.8$ (46.8 (46:3) millimeters. 


\section{Nyctanassa violacea violacea (Linnaeus) \\ YELLOW-CROWNED NIGHT HERON \\ Crab Gaulding}

Four were observed at Fox's Bay Pond on February 12, 1937. Since then R. A. Tonge has sent me an immature female collected at Cars Bay on September 20, 1937, and an adult male obtained at the same place on January 6, 1938. Not previously recorded from the island.

\section{Querquedula discors (Linnaeus) \\ BLUE-WINGED TEAL \\ Pan Duck}

I have a male collected by $\mathrm{R}$. A. Tonge at Fox's Bay Pond on September 18, 1937, constituting the first record for the island.

\section{Buteo jamaicensis jamaicensis (Gmelin) \\ WEST INDIAN RED-TAILED HAWK \\ Chicken Hawk}

A hawk, almost certainly of this race, was heard calling at an altitude of 2,000 feet on Olveston Mountain, in the Centre. Hills, on February 11, 1937, but the dense forest growth made it impossible to see or collect the bird. Bond has listed the species doubtfully from Montserrat, and residents report chicken hawks as bein seen on rare occasions.

\section{Falco peregrinus anatum Bonaparte \\ DUCK HAWK}

An example of this large migratory falcon was observed at Plymouth on February 8, 1937, and I have in my collection a male collected at Cork Hill, on January 4, 1938 and a female taken at Gingoes the same day, both collected by R. A. Tonge. Previously unrecorded from Montserrat.

Falco sparverius caribaearum Gmelin

ANTILLEAN SPARROW HAWK

Killi-killi

Common and generally distributed, most common in the lowlands, but found even in mountain forest, as on Olveston Mountain. A 
pais was collected near Plymouth on February 10, 1937, and a female the next day on Olveston Mountain. One stomach contained a large centipede, a second crickets (Gryllus sp.), and the third crickets and a ground lizard (Ameiva pluvianotata).

\section{Porzana carolina (Linnaeus)}

Recorded by Bond.

SORA RAIL

\section{Gallinula chloropus portoricensis Danforth}

\section{ANTILLEAN GALLINULE}

Coot

Ten were observed at Fox's Bay Pond on February 12, 1937, and R. A. Tonge sent me a male obtained at the same place on January 12, 1938.

\section{Fulica caribaea Ridgway \\ CARIBBEAN COOT}

\section{Coot}

R. A. Tonge has sent me 9 specimens of various ages from Montserrat. A female was collected November 4, 1937 at Old Road Pond, whereas the other 8 specimens are all from Fox's Bay Pound, as follows: Adult male, Sep. 26, 1937; immature, Dec. 11, 1937; female juvenile, Dec. 18, 1937; immature, winter 1937-8; immature, Jan. 1, 1938; immature, Jan. 5, 1938; adult male, Jan. 14, 1938; immature female, Jan. 25, 1938. Recorded previously by Bond.

\section{Totanus flavipes (Gmelin)}

\section{LESSER YELLOWLEGS}

R. A. Tonge has forwarded two females taken at Oldroad Bay on July 30, and a male shot at Hotwater Pond on August 1, 1938. First records for the island.

\section{Actitis macularia (Linnaeus)}

SPOTTED SANDPIPER

Common migrant and winter visitor. Twenty were noted near Plymouth on July 31,1931 . Three were seen and a male collected near Plymouth on February 10, 1937, and one was observed at Fox's 
Bay Pound February 12, 1937. The stomach of the bird collected contained a large black wasp, some beetles, and a few other insects; also a little sand.

\section{Arenaria interpres morinella (Linnaeus) \\ RUDDY TURNSTONE}

R. A. Tonge has sent me females collected at Hot Water Pond May 5 and 16, 1938, and a male obtained at Kinsale Bay May 15, 1938. Not previously known from the Island.

\section{Ereunetes pusillus (Linnaeus)}

\section{SEMIPALMATED SANDPIPER}

R. A. Tonge has sent me two females obtaincd at Elbertson Pond on August 4, 1938. Not previously recorded from Montserrat.

\section{Himantopus mexicanus (Müller)}

BLACK-NECKED STILT

A specimen marked male but probably female obtained at Hot Water Pond on May 3, 1938 by R. A. Tonge constitutes the first record for the island.

\section{Larus atricilla Linnaeus \\ LaUghing Gull}

Strangely enough, there are no Montserrat records for this wideranging bird, but $I$ have in my collection a male in summer plumage obtained on the nearby Island of Redonda on March 11, 1938 by R. A. Tonge. It was not previously been recorded from Redonda.

\section{Sterna hirundo hirundo Linnaeus COMMON TERN}

Five were seen at Plymouth on July 31, 1931, constituting the first record for the island.

\section{Thalasseus maximus maximus (Boddaert)}

\section{ROYAL TERN}

A female was obtained by R. A. Tonge at Oganows on May 1, 1938, and a male the following day. Not previously recorded from 
Montserrat. The same collector also sent me a male obtained on Redonda March 11, 1938, constituting the first record of the species for that island.

\section{Anoüs stolidus stolidus (Linnaeus)}

\section{NODDY TERN}

Grisdale obtained a specimen from Montserrat, and believed it to be common on the coasts. Apparently there are no other records. Mr. H. E. Box and party reported thousands nesting on the precipitous cliffs on the windward side of Redonda on July 18, 1938,

\section{[Columba leucocephala Linnaeus}

\section{WHITE-CROWNED JPIGEON}

Although this pigeon probably occurs rarely, there is no very satisfactory Montserrat record. Ridgway (U.S.N.M. Bull. 50, VII, 1916, p. 311) includes Montserrat in its range, but lists no specimen nor literature citation from there. Possibly his basis for its inclusion was a statement by Ober (Proc. U.S.N.M., I, 1878, p. 237) that he believed Antigua to be the southern limit of the breeding range of this species "except perhaps Montserrat". Until more definite information is available, I am listing the species hypothetically.]

\section{Columba squamosa Bonnaterre}

\section{SCALED PIGEON}

Pigeon

Said to be very common during the summer months, but we observed only five at St. George's Hill on February 15, 1937, and a pair at Tar River (on the windward coast) on February 16, the male of which was collected. Its crop contained 7 large green palm fruits, and 17 blueberry-like fruits known locally as "barberry".

\section{Zenaida aurita aurita (Temminck)}

\section{MARTINIQUE DOVE}

\section{Mountain Dove}

Common and generally distributed. In February 1937 we observed it in many localities, but it was particularly abundant in a wooded gully north of Plymouth, and in the vicinity of Fox's Bay Pond. Although I am listing all the Zenaida doves of the island under this name, doubtless both Z.a. zenaida and this forth both 
occur, and in fact all of the three specimens collected are intermediate between the two forms. Their crops contained exclusively lime seeds, 49, 77 and 83 seeds being found per bird. These must have been obtained from rotten or overripe fruit, as these soft-billed birds would scarcely be able to open sound limes.

\section{Columbigallina passerina nigrirostris Danforth}

ST. KITTS GROUND DOVE

Ground Dove

Fairly common in the vicinity of Plymouth; not observed elsewhere. A male collected on February 8, and a female on February 12, 1937 had the bills entirely dusky. Ground pearls (Margarodes formicarum) formed 52.5 per cent of the contents of their crops, one bird having consumed 71 and the other 50. The seeds of Typhalea formed 7.5 per cent, and other seeds 40 per cent of the contents.

\section{Oreopeleia mystacea mystacea (Temminck) \\ BRIDLED QUAIL DOVE \\ Partridge}

Rather rare. Three were noted on St. George's Hill on February 15, 1937, and two at Woodlands on February 18. Later R. A. Tonge sent males collected at Olveston Mountain March 14, 1937 and Jubilee Mountain September 30, 1937, and a female at Woodlands Mountain July 8, 1937.

\section{Coccyzus minor dominicae Shelley SHELLEY'S MANGrove CUCKOO \\ Coucou Manioc}

Fairly common, a few being observed in most of the localities visited. Three males collected in February, 1937 are much darker below than specimens of rileyi or vincentis in my collection, and undoubtedly represent dominicae. They measure, wing 134.6-140.8 (137.3) ; tail 162.2-162.9 (169.6) ; culmen from base 32.5-34.6 (33.7); tarsus 29.7-31.8 (30.7) millimeters. Their stomachs contained katydids (Microcentrum sp.) 60 per cent; long-horned grasshoppers (Neoconocephalus triops macropterus) 33.3 per cent, and Coleoptera 6.7 per cent. 


\section{Orthorhynchus cristatus exilis (Gmelin) GILT-CRESTED HUMMINGBIRD}

Abundant near the coast, and a few were observed in the mour. tain forests. A male was collected at Plymouth on February 8, and another on Olveston Mountain on February 11, 1937.

\section{Sericotes holosericeus holosericeus (Linnaeus)}

\section{BLUE-BREASTED HUMMINGBIRD}

Much less common than the previous species; observed only near Plymouth, on St. George's Hill, and at Woodlands. The stomach of a male collected at Plymouth on February 12, 1937 was filled with minute insects.

\section{Eulampis jugularis (Linnaeus)}

\section{GARNET-THROATED HUMMINGBIRD}

Fairly common in the forests on Soufriere Mountain, Olveston Mountain, and at Woodlands. A pair was collected on Soufriere Mountain on February 9, and two males at Woodlands on February 18, 1937. Small spiders formed 88.7 per cent, Coleoptera 6.3 per cent, and a Dolichopodid fly 5 per cent of the contents of the four stomachs.

\section{Megaceryle alcyon alcyon (Linnaeus) \\ BELTED KINGFISHER}

Not seen in the course of our work, although the species is well known as a winter resident in Montserrat. Sturge sent a female to the British Museum. Grisdale saw it frequently in February, 1881, and Dr. Pilkington procured one for him. Nicoll shot a female on February 11, 1904. R. A. Tonge has sent me a specimen obtained at Isles Bay in the spring of 1938.

\section{Tyrannus dominicensis vorax Vieillot \\ LARGE-BILLED KINGBIRD}

Rather common in the vicinity of Plymouth, and at Elberton on February 12, 1937 a congregation of fifty or more was noted on a hill near the pond. Two females which were collected from this group are as light as any specimens of $T$. $d$. dominicensis in my collection. The culmen from base measures 31.3 and 32.7 , and the 
width at frontal antiae 15.5 and 16 millimeters. These measurements are larger than the average for dominicensis, so the specimens are probably best regarded as intermediate between dominicensis and vorax.

One stomach contained 7 syrphid flies (Volucella obesa), while the other had 6 Volucella obesa and 5 stratiomyid flies (Hermetia illucens).

\section{Elaenia martinica riisii Sclater RIISE'S ELAENIA}

Common and generally distributed, although found most abundantly at lower elevations. Six specimens (three males and three females) were collected at Plymouth, Soufriere Mountain, Cassel's Peak, Olveston Mountain, and Woodlands. As I have shown elsewhere (Journal of the Barbados Museum and Historical Society, V, 1938, p. 123), these specimens are referable to riisii.

The six stomachs contained exclusively drupes and berries, among which the fruits of some wild species of Solanum amounted to 17 per cent.

\section{Progne dominicensis (Gmelin)}

CARIBBEAN MARTIN

\section{Swallow}

Small numbers were observed at Plymouth on June 30 and August 13, 1935, and at Fox's Bay Pond on February 12, 1937. Not previously recorded from the island.

\section{Margarops fuscatus densirostris (Vieillot) \\ DARKER PEARLY-EYED THRASHER}

Thrush

Found in practically all wooded regions, but particularly common on the lower wooded hills and in densely wooded ravines in the coastal region. Densirostris is a rather dubious race, but if it is to be recognized Montserrat birds must be referred to it. A male was collected on the Soufriere Mountain February 9, 1937, a pair (at one shot) near Plymouth on February 12, and a female at Fox's Bay Pond the same day.

The contents of the four stomachs consisted of walking sticks 25 per cent; weevils 2 per cent; a large spider 5 per cent; berries 63 per cent; and drupes 5 per cent. 


\author{
Allenia fusca (P. L. S. Müller) \\ SCALY-BREASTED THRASHER \\ Black-billed Thrush
}

On Montserrat this species is scarcer and shyer than Margarops. Three were observed on the Soufriere Mountain on February 9, two on St. George's Hill February 15, and fifteen at Woodlands on February 18, 1937. On the latter occasion a female was taken. Its stomach was filled with drupes.

\title{
Cinclocerthia ruficauda pavida Ridgway
}

ST. IITTTS TREMBLER

\section{Trembling Thrush}

Far from common on Montserrat. One was observed singing on February 9, 1937 at the edge of the tree fern forest on the Soufriere Mountain; another was seen at a slightly higher altitude on Cassel's Peak on February 16, and five at an altitude of only 800 feet at Woodlands on February 18, when three males were collected. These are much more rufescent above, and to some extent below, than C.r. tenebrosa from St. Vincent. They measure: Wing 96.2-103 (99.9); tail 80.7-85.4 (83.6); culmen from base 37.5-39.8 (38.8); tarsus 30.3-32.8 (31.5) millimeters.

The specimens all had the iris light yellow, bill black, legs and feet yellowish brown, somewhat tinged with dusky; claws dusky yellowish brown; soles of feet dull yellow.

The three stomachs contained land snalls (identified by Dr. Paul Bartsch as Helicina fasciata Lamarck), 36 per cent; a large spider 13.3 per cent; katydid nymphs (Microcentrum sp.), 26.7 per cent; a long-horned beetle (Elaphidion sp.), 4 per cent; weevils 1.7 per cent; other beetles 5 per cent; soft-meated seeds, 13.3 per cent.

\section{Cichtherminia lherminieri lawrencei Cory}

\section{MONTSERRAT FOREST THRUSH}

Yellow-legged Thrush

Rare and shy, occurring only in the mountain forests. A female was collected at about 2,500 feet elevation on the Soufriere Mountain on February 9, and a bird was observed on Cassel's Peak February 16, 1937. R. A. Tonge sent a male collected on Jubilee Mountain September 30, 1937, a female from Gage's Mountain August 4, 
1938, and a pair from the same locality August 6, 1938. These specimens exhibit the color differences noted by Ridgway (U.S.N.M. Bulletin $50, I V, 1907$, p. 75 ) as distinguishing lawrencei from typical Therminieri. Also lawrencei seems to average somewhat smaller. Two males from Montserrat measure, wing 127.8-130.7 (129.2); tail 86.4-89 (87.7) ; culmen from base 28.3-30.6 (2.94), and tarsus 39.741.7 (40.7) millimeters, while three females measure wing 131.6-136 (133.8); tail 92.7-95 (93.8) in two; culmen from base 29.6-30.5 (30.0), and tarsus 41-42 (41.6) millimeters. Two adult males of C. . Iherminieri from Guadeloupe in my collection measure: wing 137.1-139 (138); tail 91.2-92.8 (92); culmen from base 29.9-31.1 (30.5); tarsus 41.6-42.6 (42.1) millimeters.

The adult female lawrencei collected had the bare orbital space, bill, legs and feet, including the claws and soles, bright orange yellow, except that the upper mandible was more or less tinged with dusky. The iris was hazel. Its stomach contained about equal parts of insect remains and fragments of fruits.

\section{Vireo calidris barbadensis (Ridgway)}

BARBADOS VIREO

Common at lower elevations, but not observed in the mountain forests. None were observed during the first few days of our visit, but on February 10 many were seen and heard singing in the very same area near Plymouth where none had been recorded a few days previously. From that date on the species was observed commonly. Males were collected near Plymouth on February 10 and 12, and a pair on St. George's Hill on February 15, 1937. Drupes constituted 50 per cent, Coleoptera 25 per cent, and a large Coleopterous larva 25 per cent of the contents of the four stomachs.

\section{Coereba bartholemica (Sparrmann) \\ ST. BARTS HONEY CREEPER}

\section{Yellow-breast}

Common at lower elevations; scarce in the mountain forests. Two females were collected on Olveston Mountain February 11, a female at Plymouth, February 12, and a male on Cassel's Peak February 16, 1937. I cannot distinguish these from specimens from the more northern Lesser Antilles or Guadeloupe, and consequently consider that dominicana must be regarded as a synonym of bartho- 
lemica. One of the females has a decidedly white front, and another shows some indications of white in that region. The male measures, wing 59.8; tail 38.8 ; culmen from base 16 ; tarsus 18.5, and the three females, wing 57-62.4 (58.8); tail 37.8-41.5 (39.3); culmen from base 16.1-17 (16.5) ; tarsus 18-18.2 (18.1) millimeters.

One stomach was empty. The others contained exclusively insects and their larvae, among which Coleoptera 32 per cent and lepidopterous larvae 50 per cent were recognizable.

\section{Mniotilta varia (Linnaeus) \\ BLACK AND WHITE WARBLER}

A female was collected in a ravine north of Plymouth on February 12, and an individual was noted at Woodlands on February 18, 1937. The stomach of the specimen collected contained comminuted insects and their larvae, including weevils and other Coleoptera, and lepidopterous larvae. Previously recorded by Bond.

\section{Compsothlypis americana pusilla (Wilson) NORTHERN PARULA WARBLER}

Observed near Plymouth on February 7 and 8, 1937. Nicoll found the species fairly common and shot two on February 11, 1904.

\section{Dendroica petechia bartholemica Sundevall}

ST. BARTS GOLDEN WARBLER

Fairly common in dry scrub near Plymouth; also observed in manchineels along the coast. A male was collected on February 10, and a female February 12, 1937 in scrub country near Plymouth. The male has scarcely any chestnut on the crown, in which respect it resembles other males of its race in my collection. It measures, wing 63.6 ; tail 51.6 ; culmen from base 15 ; tarsus 22 millimeters, and the female, wing 57.7; tail 47; culmen from base 14.2, and tarsus 20.6 millimeters. Their stomachs contained fragments of insects and their larvae, including Chrysomelidae 10 per cent, other Coleoptera 37.5 per cent, and lepidopterous larvae 30 per cent.

\section{Dendroica tigrina (Gmelin)}

Recorded by Bond. 


\section{Dendroica dominica dominica (Linnaeus)}

\section{YELLOW-THROTED WARBLER}

Nicoll records one shot in thorn bushes along the shore on February 11, 1904.

\section{Dendroica discolor discolor (Vieillott)}

\section{NORTHERN PRAIRIE WARBLER}

One was shot in dry scrub country near Plymouth on February 10, and two were seen and one collected there on February 12, 1937. The stomach of the latter contained a spider and various insects, including Coleoptera. Previously recorded by Bond.

\section{Seiurus aurocapillus (Linnaeus)}

$$
\text { OVEN-BIRD }
$$

Recorded by Bond.

\section{Seiurus noveboracensis (Gmelin)} NORTHERN WATER-THRUSH

One was seen in the mangroves at Fox's Bay Pond on February 12, 1937, constituting the first record for the island.

\section{Seiurus motacilla (Vieillot)}

LOUISIANA WATER-THRUSH

Recorded by Bond.

\section{Setophaga ruticilla (Linnaeus)}

\section{AMERICAN REDSTART}

Many were seen, including some in bright male plumage, and others in female or immature male plumage, from February 9 to 16 , 1937 in all parts of the island from mountain forests to the coast. An immature male collected on the Soufriere Mountain on February 9, 1937 had eaten fleabeetles, weevils and Diptera. Nicoll obtained one and saw others on February 11, 1904.

\section{Icterus oberi Lawrence MONTSERRAT ORIOLE \\ Tanya Bird}

This, the only distinct species confined to Montserrat, occurs in forests on the Soufriere and also on Olveston Mountain in the Centre 
Hills, and down to as low as 800 feet elevation at Woodlands, so it is by no means confined in its distribution to the Soufriere Mountain, as has previously been supposed. A total of eight specimens were obtained (including some sent by $R$. A. Tonge since our departure), obtained on the Soufriere Mountain, Cassel's Peak Chance's Mountain, Rendezvous Mountain, Woodland Mountain, and at Woodlands. In these, there are five adult males, one immature male, and two adult (?) females. There has been some doubt concerning the plumage of the adult female of this species. If these two females are indeed adult, then the female plumage is indistinguishable from that of the immature male. Three of the specimens obtaind by Ober, which I have examined in the Field Museum, are in this plumage, and are marked immature female. Possibly they are actually adult, as no females appear to have been collected in any other plumage.

The song of this species was not heard. The call note is similar to that of $I$. portoricensis but not quite so loud.

An adult male and a female collected on Cassel's Peak February 16, 1937 both had the iris dark brown; upper mandible black, the lower light slate blue except for the median surface, which was black, and the extreme tips of both mandibles light horn color; legs and feet light slate blue, the soles tinged with yellow, and the claws bluish slate. An immature male collected at Woodlands February 18, 1937 was very similar.

One stomach was nearly empty, containing only single weevil. Another contained a rotten cane borer weevil (Metamasius hemipterus), 3 lepidopterous larvae, 6 cockroach oöthecae, and some miscellaneous insect fragments.

\section{Holoquiscalus lugubris guadeloupensis (Lawrence) GUADELOUPE GRACKLE}

\section{Blackbird}

Mr. English informs me that this species was well established in Montserrat at the time of his arrival in 1919, but that he has heard conflicting tales concerning which island was the source of the stock used for introduction. There are no references in the literature prior to Bond (1936). It is even now far from common. On July 31, 1931 I observed a few in mangroves near Plymouth, and in 1937 a 
few were seen near Fox's Bay Pond, and in the growth back of beaches near Plymouth, where an apparently mated pair was collected on February 12. These agree well with specimens from Guadeloupe in my collection. The female is much lighter than specimens of inflexirostris. The male measures: Wing 124.5; tail 103; culmen from base 32 ; tarsus 34.8 millimeters, and the female, wing 105.2; tail, in molt; culmen from base 28.7 ; tarsus 31.6 millimeters.

There is some possibility that the species is a recent arrival from Guadeloupe and was not introduced, but it seems highly improbable that it could have existed in the island for long, since so conspicuous a bird could hardly have been overlooked by the earlier collectors.

The stomach contents of the pair collected consisted of Anolis lizards 75 per cent; mealybugs, Pseudococcus sp., (40 in one stomach), 15 per cent; Coleoptera 6 per cent, and spiders 4 per cent.

\section{Tanagra flavifrons flavifrons (Sparrmann)}

GREEN EUPHONIA

Heard calling on several occasions in February, 1937 in the forests on Soufriere Mountain, Cassel's Peak, Olveston Mountain, and at Woodlands, but it proved impossible to collect any.

\section{Tiaris bicolor omissa Jardine \\ CARIB GRASSQUIT}

Abundant in the vicinity of Plymouth; not seen elsewhere. Two males and a female were collected in February, 1937. On June 30, 1935, a nest and two eggs were collected seven feet from the ground in a manchineel tree near the beach. The female emerged from the nest, and scolded vigorously as it was being collected. The eggs are white, more or less uniformly covered with fine red speckles. One measured $16.4 \times 12.8$ millimeters, the other was broken before it could be measured.

Three stomachs contained seeds of grasses and other small seeds, with the addition of sand for grinding purposes.

\section{Loxigilla noctis dominicana (Ridgway}

\section{DOMINICA BULLFINCH}

Rather uncommon; during the course of our field work exactly 16 birds were noted. These were found widely seattered and in many types of country, ranging from dry scrub near Plymouth to 
mountain forest on Soufriere Mountain and Cassel's Peak. Two adult males and three females were collected. These agree well with specimens from Guadeloupe and Dominica, and are regarded as dominicana. Two males measure: Wing 70-70.1 (70.05); tail 5052.3 (51.15); culmen from base 16.4-16.7 (16.55); tarsus 19.3-20.3 19.8 millimeters, and three females, wing $61.8-65$ (63.8); tail $45-49.3$ (47.4); culmen from base 15.3-15.6 (15.4); tarsus 19-19.6 (19.4) millimeters.

The stomachs of the five birds collected contained small seeds 80 per cent and fruit pulp 20 per cent, plus sand or gravel for grinding purposes. 